\title{
Interpretação da prova tuberculínica
}

\section{Interpretation of the tuberculin test}

Ribeirão Preto, 25 de maio de 2006.

Prezado Editor,

Dado que a prova tuberculínica é um importante instrumento para o diagnóstico da forma latente da tuberculose, julgo de extrema importância divulgar um belo exercício envolvendo a epidemiologia, os modelos matemáticos ou probabilísticos e a bacteriologia pertinentes à referida prova na realidade brasileira. O exercício é elaborado com cinco trabalhos científicos publicados no Brasil: o primeiro trabalho levanta uma hipótese epidemiológica da existência de micobactérias atípicas; o segundo analisa matematicamente a hipótese; o terceiro apresenta uma prova bacteriológica; o quarto analisa a probabilidade de se cometer erros; e o último, publicado em 2003, reanalisou os dados anteriores sob a ótica Bayesiana.

Quando se analisa a distribuição dos diâmetros das reações tuberculínicas, obtidas em uma população, e, dispostas em forma de histograma de freqüências relativas, é possível obter diversas informações: aquilatar qualidade técnica com a qual os testes foram lidos bem como analisar o comportamento biológico da população face a infecções por micobactérias.

Arantes et $\mathrm{al}^{2}$ (1976), ao analisarem os resultados de 35.680 provas tuberculínicas efetuadas na cidade de Ribeirão Preto, levantaram a hipótese da existência de infecções por micobactérias anônimas nessa área, além de constatar a ocorrência diversificada dessas infecções nos grupos etários. Mostraram evidências que alguma epidemia teria ocorrido na cidade entre 1950/ 1955, com a disseminação da referida micobactéria. Estava assim colocada a hipótese epidemiológica.

Ruffino-Netto et $\mathrm{al}^{4}$ (1977) retomaram os dados anteriores e aplicaram o Método de Bhattacharya (para decomposição de mistura de distribuições), confirmando matematicamente a hipótese epidemiológica levantada.
Faltava a prova bacteriológica: Angerami ${ }^{1}$ (1977) publicou que amostras de água de Ribeirão Preto, coletadas em 1951/1952, foram analisadas à época na Suíça e identificadas micobactérias atípicas nessas amostras. Verificou-se na ocasião que vários poços artesianos da cidade estavam contaminados pela micobactéria e providências foram tomadas para seu controle, interrompendo-se sua disseminação (esclarecendo o porquê das prevalências diferentes nos vários grupos etários). A prova bacteriológica vinha confirmar a hipótese epidemiológica (analisada e não contestada matematicamente).

A partir dessas observações, Sanches et $\mathrm{al}^{5}$ (1977) analisaram a probabilidade de erros cometidos nas leituras da prova, até então feitas seguindo os critérios do Ministério da Saúde.

Recentemente, ainda interessados no estudo da distribuição dos diâmetros das reações tuberculínicas (em geral dada pela mistura de duas ou mais distribuições de probabilidades), Martinez et $\mathrm{al}^{3}$ (2003) tomaram os resultados dos 35.680 testes citados e os analisaram sob um modelo Bayesiano (utilizando métodos de simulação baseados em algoritmos de Monte Carlo em cadeia de Markov).

A presente carta tem a intenção apenas de estimular aos estudiosos do assunto, o exercício de seguir a intuição advinda da epidemiologia, buscar os fundamentos quantitativos (matemáticos e probabilísticos), e finalmente, mostrar a prova bacteriológica da hipótese levantada, e analisar os erros cometidos na leitura da prova tuberculínica.

Antonio Ruffino-Netto Faculdade e Medicina de Ribeirão Preto Universidade de São Paulo Rede Brasileira de Pesquisas em Tuberculose 


\section{REFERÊNCIAS}

1. Angerami D. Micobactérias atípicas. Rev Div Nac Tub. 1977;21:434-5.

2. Arantes $G R$, Ruffino-N etto $A, N$ assar J. Interpretação da sensibilidade tuberculínica em população do interior do Estado de São Paulo. Rev Saúde Pública. 1976;10:219-26.

3. Martinez EZ, Achcar JA, Ruffino-N etto A. Análise dos resultados da prova tuberculínica: uso de métodos Bayeseanos. Rev Bras Estat Rio de Janeiro. 2003;64(22):25-41.
4. Ruffino-N etto A, Sanches O, Arantes GR. Aplicação do Método de Bhatacharya na análise de resultados do teste tuberculínico. Rev Saúde Pública. 1977;11:322-9.

5. Sanches O, Arantes GR, Ruffino-Netto A. Probabilidade de classificação errada no teste tuberculínico segundo critério em vigor. Rev Div Nac Tub. 1977;21:288-95. 